\title{
Dipeptidyl peptidase IV inhibitors in diabetes: more than inhibition of glucagon-like peptide-1 metabolism?
}

\author{
Martin C. Michel • Eric Fliers • \\ Cornelis J. F. Van Noorden
}

Published online: 9 April 2008

(C) The Author(s) 2008

\begin{abstract}
Inhibitors of the protease dipeptidyl peptidase IV (DPP-IV) are promising new drugs for the treatment of type 2 diabetes. They are thought to act by inhibiting the breakdown of glucagon-like peptide-1 and, thereby, selectively enhancing insulin release under conditions when it is physiologically required. These drugs are selective for DPP-IV, but the enzyme itself has a broad range of substrates other than glucagon-like peptide-1. Other high affinity substrates of DPP-IV including peptide YY may also play a role in the regulation of energy homeostasis. Moreover, DPP-IV is also known as CD26 and considered to be a moonlighting protein because it has a wide range of other functions unrelated to energy homeostasis, e.g. in immunity. The potential role of DPP-IV inhibition on substrates other than glucagon-like peptide-1 in diabetes patients remains to be elucidated.
\end{abstract}

Keywords Dipeptidyl peptidase IV.

Glucagon-like peptide-1 · Peptide YY · Diabetes · CD26

M. C. Michel $(\bowtie)$

Department of Pharmacology and Pharmacotherapy,

Academic Medical Center, University of Amsterdam,

Meibergdreef 15,

1105 AZ, Amsterdam, The Netherlands

e-mail:m.c.michel@amc.nl

E. Fliers

Department of Endocrinology and Metabolism,

Academic Medical Center, University of Amsterdam,

Meibergdreef 15,

1105 AZ, Amsterdam, The Netherlands

C. J. F. Van Noorden

Department of Cell Biology and Histology,

Academic Medical Center, University of Amsterdam,

Meibergdreef 15,

1105 AZ, Amsterdam, The Netherlands
Glucagon-like peptide-1 (GLP-1) is a hormone which is released following meals and stimulates insulin release from the pancreas. Its effects are terminated by breakdown by the enzyme dipeptidyl peptidase IV (DPP-IV). Therefore, inhibition of DPP-IV increases GLP-1 levels in the circulation and, hence, insulin release under conditions when it is needed, i.e. after a meal but not during fasting. Consequently, inhibition of GLP-1 inactivation is an insulinotropic principle which is unlikely to cause hypoglycaemia between meals. The lower risk for hypoglycaemic events as compared with other insulinotropic or insulin-sensitising agents makes DPP-IV inhibitors very promising candidates for a more physiological treatment of type 2 diabetes (Combettes and Kargar 2008).

In recent years, a number of selective DPP-IV inhibitors such as vildagliptin and sitagliptin have been evaluated in clinical trials (Hermansen et al. 2007; Utzschneider et al. 2008) and may have a future role in the treatment of type 2 diabetes (Combettes and Kargar 2008). In this issue of the journal, a novel DPP-IV inhibitor, ASP8497, is being introduced, which is highly selective for DPP-IV as compared to other peptidases (Someya et al. 2008). However, DPP-IV itself is not selective for GLP-1 but has a wide range of other natural substrates (Boonacker and Van Noorden 2003). Therefore, we wish to highlight potential implications of this lack of selectivity of DPP-IV for the use of DPP-IV inhibitors in diabetes treatment.

Another high affinity substrate of DPP-IV is peptide YY (PYY; Mentlein et al. 1993). Whereas cleavage of GLP-1 by DPP-IV causes inactivation, cleavage of PYY yields the long C-terminal fragment $\mathrm{PYY}_{3-36}$, which is inactive at some but active at other subtypes of PYY receptors. Specifically, it converts the non-subtype-selective agonist PYY into a selective agonist at $Y_{2}$ and $Y_{5}$ receptors 
(Michel et al. 1998). Thus, DPP-IV does not inactivate PYY but, rather, qualitatively alters its biological activity.

Indeed it has been reported that peripherally adminis-

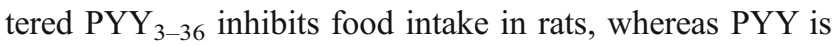
a potent central stimulator of food intake (Batterham et al. 2002). Given the role of obesity in type 2 diabetes, prevention of the formation of such an endogenous food intake inhibitor by a DPP-IV inhibitor may be undesirable. It has been proposed that the effects of peripherally administered $\mathrm{PYY}_{3-36}$ on central nervous functions such as food intake may be mediated by excitation of afferent vagal fibres (Koda et al. 2005). However, the majority of subsequent rodent studies did not confirm inhibition of food intake by $\mathrm{PYY}_{3-36}$, particularly not following chronic administration (Boggiano et al. 2005). On the other hand, recent studies in non-rodents such as pigs (Ito et al. 2006) or humans (Degen et al. 2005; Sloth et al. 2007a; Sloth et al. 2007b) have reported reduced food intake upon peripheral administration of $\mathrm{PYY}_{3-36}$ but typically, these effects were found only at relatively high concentrations. Moreover, the effect of $\mathrm{PYY}_{3-36}$ on food intake was biphasic, depending on the duration of its administration (Parkinson et al. 2008). Two additional findings deserve consideration. Firstly, $\mathrm{PYY}_{3-36}$ was reported to promote fat oxidation and ameliorate insulin resistance in mice even under conditions of chronic administration where it did not reduce food intake (van den Hoek et al. 2006). Secondly, $\mathrm{PYY}_{3-36}$ was reported to lower plasma glucose levels even in the absence of alterations in circulating insulin levels (Bischoff and Michel 1998).

Taken together, the presently available data on $\mathrm{PYY}_{3-36}$ on food intake and metabolic parameters are not yet conclusive. However, it is clear that $\mathrm{PYY}_{3-36}$ is largely formed by DPP-IV, raising the possibility that selective DPP-IV inhibitors may exert part of their effects by modulating the PYY/PYY ${ }_{3-36}$ ratios. Therefore, it remains to be explored how possible effects on PYY cleavage contribute to metabolic effects of DPP-IV inhibitors in diabetic patients.

Moreover, DPP-IV is not only a protease for substrates relevant to energy homeostasis, but it also has a range of additional functions (Boonacker and Van Noorden 2003). Therefore, it is considered to be a moonlighting protein. As a protease, it has several other substrates, and it also acts as a receptor and costimulatory protein in the immune system. In this regard, CD26 is considered to be an important regulator of T-cell function (Reinhold et al. 2008). These pleiotropic effects of DPP-IV or CD26 lead to numerous potential uses of its inhibitors other than type 2 diabetes including inflammatory diseases (Ohnuma et al. 2006; Reinhold et al. 2007; Thielitz et al. 2008; Thompson et al. 2007) and, perhaps, certain types of cancers (Kikkawa et al. 2005; Thompson et al. 2007). Some of these effects may manifest as useful secondary actions when being used for the treatment of diabetic patients whereas others may manifest as adverse events. Most of these potential additional effects may not yet have manifested in the currently published diabetes literature, but it appears prudent to keep an eye on them.

Open Access This article is distributed under the terms of the Creative Commons Attribution Noncommercial License which permits any noncommercial use, distribution, and reproduction in any medium, provided the original author(s) and source are credited.

\section{References}

Batterham RL, Cowley MA, Small CJ, Herzog H, Cohen MA, Dakin CL, Wren AM, Brynes AE, Low MJ, Ghatei MA, Cone RD, Bloom SR (2002) Gut hormone PYY $_{3-36}$ physiologically inhibits food intake. Nature 418:650-654

Bischoff A, Michel MC (1998) Neuropeptide Y lowers blood glucose in anaesthetized rats via a $\mathrm{Y}_{5}$ receptor subtype. Endocrinol 139:3018-3021

Boggiano MM, Chandler PC, Oswald KD, Rodgers RJ, Blundell JE, Ishii Y, Beattie AH, Holch P, Allison DB, Schindler M, Arndt K, Rudolf K, Mark M, Schoelch C, Joost HG, Klaus S, ThöneReineke C, Benoit SC, Seeley RJ, Beck-Sickinger AG, Koglin N, Raun K, Madsen K, Wulff BS, Stidsen CE, Birringer M, Kreuzer OJ, Deng XY, Whitcomb DC, Halem H, Tayloer J, Dong J, Datta R, Culler M, Ortmann S, Castaneda TR, Tschöp M (2005) PYY3-36 as an anti-obesity drug target. Obesity Rev 6:307-322

Boonacker E, Van Noorden CJF (2003) The multifunctional or moonlighting protein CD26/DPPIV. Eur J Cell Biol 82:53-73

Combettes M, Kargar C (2008) Newly approved and promising antidiabetic agents. Therapie 62:293-310

Degen L, Oesch S, Casanova M, Graf S, Ketterer S, Drewe J, Beglinger C (2005) Effect of peptide $\mathrm{YY}_{3-36}$ on food intake in humans. Gastroenterology 129:1430-1436

Hermansen K, Kipnes M, Luo E, Faurik D, Khatami H, Stein P (2007) Efficacy and safety of the dipeptidyl peptidase-4 inhibitor, sitagliptin, in patients with type 2 diabetes mellitus inadequately controlled on glimepiride alone or on glimepiride and metformin. Diabetes, Obesity \& Metab 9:733-745

Ito T, ThidayMyint $\mathrm{H}$, Murata $\mathrm{T}$, Inoue $\mathrm{H}$, Neyra RM, Kuwayama $\mathrm{H}$ (2006) Effects of peripheral administration of $\mathrm{PYY}_{3-36}$ on feed intake and plasma acyl-ghrelin levels in pigs. $\mathrm{J}$ Endocrinol 191:113-119

Kikkawa F, Kajiyama H, Shibata K, Ino K, Nomura S, Mizutani S (2005) Dipeptidyl peptidase IV in tumor progression. Biochim Biophys Acta 1751:45-51

Koda S, Date Y, Murakami N, Shimbara T, Hanada T, Toshinai K, Niijima A, Furuya M, Inomata N, Osuye K, Nakazato M (2005) The role of the vagal nerve in peripheral $\mathrm{PYY}_{3-36}$-induced feeding reduction in rats. Endocrinol 146:2369-2375

Mentlein R, Dahms P, Grandt D, Krüger R (1993) Proteolytic processing of neuropeptide $\mathrm{Y}$ and peptide $\mathrm{YY}$ by dipeptidyl peptidase IV. Regul Pept 49:133-144

Michel MC, Beck-Sickinger AG, Cox H, Doods HN, Herzog H, Larhammar D, Quirion R, Schwartz TW, Westfall TC (1998) XVI. International Union of Pharmacology recommendations for the nomenclature of neuropeptide $\mathrm{Y}$, peptide $\mathrm{YY}$ and pancreatic polypeptide receptors. Pharmacol Rev 50:143-150 
Ohnuma K, Inoue H, Uchiyama M, Yamochi T, Hosono O, Dang NH, Morimoto C (2006) T-cell activation via CD26 and caveolin-1 in rheumatoid synovium. Mod Rheumatol 16:3-13

Parkinson JRC, Dhillo WS, Small CJ, Chaudhri OB, Bewick GA, Pritchard I, Moore S, Ghatei MA, Bloom SR (2008) PYY $3-36$ injection in mice produces an acute anorexigenic effect followed by a delayed orexigenic effect not observed with other anorexigenic gut hormones. Am J Physiol (in press)

Reinhold D, Bank U, Täger M, Ansorge S, Wrenger S, Thielitz A, Lendeckel U, Faust J, Neubert K, Brocke S (2008) DP IV/CD26, $\mathrm{APN} / \mathrm{CD} 13$ and related enzymes as regulators of $\mathrm{T}$ cell immunity: implications for experimental encephalomyelitis and multiple sclerosis. Front Biosci 13:2356-2363

Reinhold D, Biton A, Goihl A, Pieper S, Lendeckel U, Faust J, Neubert K, Bank U, Täger M, Ansorge S, Brocke S (2007) Dual inhibition of dipeptidyl peptidase IV and aminopeptidase $\mathrm{N}$ suppresses inflammatory immune responses. Ann N Y Acad Sci 1110:402-409

Sloth B, Davidsen L, Holst JJ, Flint A, Astrup A (2007a) Effect of subcutaneous injections of $\mathrm{PYY}_{1-36}$ and $\mathrm{PYY}_{3-36}$ on appetite, ad libitum energy intake, and plasma free fatty acid concentration in obese males. Am J Physiol 293:E604-E609

Sloth B, Holst JJ, Flint A, Gregersen NT, Astrup A (2007b) Effects of $\mathrm{PYY}_{1-36}$ and $\mathrm{PYY}_{3-36}$ on appetite, energy intake, energy expenditure, glucose and fat metabolism in obese and lean subjects. Am J Physiol 292:E1062-E1068

Someya Y, Tahara A, Nakano R, Matsuyama-Yokono A, Nagase I, Fukunaga Y, Takasu T, Hayakawa M, Shibasaki M (2008) Pharmacological profile of ASP8497, a novel, selective and competitive dipeptidyl peptidase-IV inhibitor, in vitro and in vivo. Naunyn-Schmiedeberg's Arch Pharmacol (in press). DOI 10.1007/ s00210-008-0277-8

Thielitz A, Ansorge S, Bank U, Tager M, Wrenger S, Gollnick H, Reinhold D (2008) The ectopeptidases dipeptidyl peptidase IV (DP IV) and aminopeptidase N (APN) and their related enzymes as possible targets in the treatment of skin disease. Front Biosci 13:2364-2375

Thompson MA, Ohnuma K, Abe M, Morimoto C, Dang NH (2007) CD26/dipeptidyl peptidase IV as a novel therapeutic target for cancer and immune disorders. Mini Rev Med Chem 7:253-273

Utzschneider KM, Tong J, Montgomery B, Udaysankar J, Gerchman F, Marcovina SM, Watson CE, Ligueros-Saylan M, Foley JE, Holst JJ, Deacon CF, Kahn SE (2008) The dipeptidyl peptidase-4 inhibitor vildagliptin improves $\beta$-cell function and insulin sensitivity in subjects with impaired fasting glucose. Diabetes Care 31:108-113

van den Hoek AM, Heijboer AC, Voshol PJ, Havekes LM, Romijn JA, Corssmit EPM, Pijl H (2006) Chronic PYY $3-36$ treatment promotes fat oxidation and ameliorates insulin resistance in C57BL6 mice. Am J Physiol 292:E238-E245 